\title{
Comparison between the effects of flipped class and traditional methods of instruction on satisfaction, active participation, and learning level in a continuous medical education course for general practitioners
}

\author{
Khoshnoodi Far $\mathbf{M}^{1}$, Mohajerpour $\mathbf{R}^{2}$, Rahimi $\mathbf{E}^{3}$, Roshani $\mathbf{D}^{4}$, Zarezadeh $\mathbf{Y}^{5}$ \\ 1. Assistant Professor of E-learning Planning, E-learning Planning in Medical Sciences Department, School of Management \\ \& Medical Education, Shahid Beheshti University of Medical Sciences,Tehran, Iran. \\ 2. MSc Student of Medical Education, Department of Medical Education, Shahid Beheshti University of Medical Sciences, \\ Tehran, Iran. \\ 3. Assistant Professor of Heart Specialist, Department of Internal Medicine, Kurdistan University of Medical Sciences, \\ Sanandaj, Iran. \\ 4. Associate Professor of Biostatistics, Social Determinants of Health Research Center, Research Institute for Health \\ Development, Kurdistan University of Medical Sciences, Sanandaj, Iran. \\ 5. Associate Professor of Medical Education, Social Determinants of Health Research Center, Research Institute for Health \\ Development, Kurdistan University of Medical Sciences, Sanandaj, Iran, (Corresponding Author) Tel: +98-87-33664656, \\ Email: y.zarezadeh@muk.ac.ir
}

\begin{abstract}
Background and Aim: Physicians' knowledge and capabilities decrease over time; therefore, continuous medical education is important. Flipped class is a blended teaching method that inverts instructional cycle by delivering the educational content by innovative technology out-of-class.

The aim of this study was to determine the effects of flipped class on satisfaction, active participation, and learning levels in general practitioners attending continuous medical education courses in the Kurdistan University of Medical Sciences in 2017.

Material and Methods: This interventional study included 120 general practitioners in Sanandaj who were attending the continuous medical education courses. They were randomly assigned to intervention (flipped class) and control (traditional class) groups. Data were collected by a researcher-made questionnaire in order to evaluate participant satisfaction, and a researcher made checklist for evaluation of active participation and a set of post-test questions for assessment of knowledge. The validity and reliability of the questionnaire and the checklist were assessed by using expert panels and measurement of Cronbach's alpha respectively.Two weeks prior to the designated day, the intervention group started educational activities by finding answers to the questions. The control group did not receive any instruction until the designated day of the classes. On the designated day the control group listened to the lectures in traditional way. The educational content delivered to both groups was identical.

Results: The results of the study showed that all the participants were satisfied with the continuous medical education classes. However, the mean satisfaction level of the re-training period was significantly higher in the intervention group $(\mathrm{P}=$ $0.001)$. The mean post-test score in the intervention group $(15.50 \pm 2.25)$ was significantly higher than that in the control group $(12.85 \pm 2.18)(\mathrm{P}=0.0001)$. Also, the mean score of participation in the intervention group $(9.01 \pm 1.71)$ was significantly higher compared to that in the control group $(7.60 \pm 2.02)(\mathrm{P}=0.0001)$.

Conclusion: The results of this study showed that flipped classroom strategy was an effective way of continuous education programs for general practitioners. This approach not only improved the knowledge of physicians after continuous medical education programs, but also increased their satisfaction by increasing their active participation.
\end{abstract}

Keywords: Inverse education, Flipped class, Continuing education, General practitioners, Satisfaction

Recevied: Feb 12, 2019

Accepted:Dec 22, 2018

How to cite the article: Khoshnoodifar M, Mohajerpour R, Rahimi E, Roshani D, Zarezadeh Y. Comparison between the effects of flipped class and traditional methods of instruction on satisfaction, active participation, and learning level in a continuous medical education course for general practitioners. SJKU 2019; 24 (1): 56-65.

Copyright $(\mathcal{C} 2019$ the Author (s). Published by Kurdistan University of Medical Sciences. This is an open access article distributed under the terms of the Creative Commons Attribution-Non Commercial License 4.0 (CCBY$\mathrm{NC}$ ), where it is permissible to download, share, remix, transform, and buildup the work provided it is properly cited. The work cannot be used commercially without permission from the journal. 


\section{مقايسه تاثير كلاس وارونه (Flipped Class) و روش سنتى بر رضايت، مشاركت فعال و ميزان

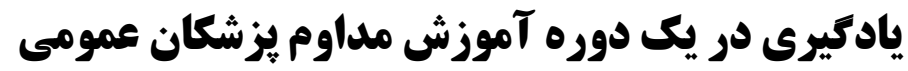

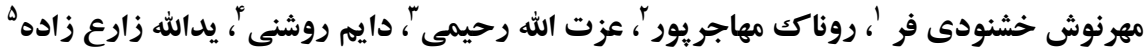

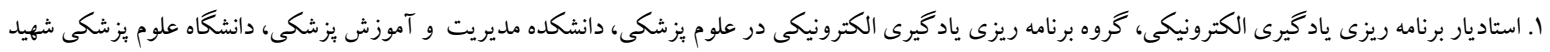
بهشتى، تهران، ايران.

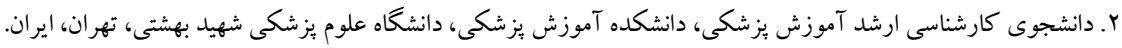

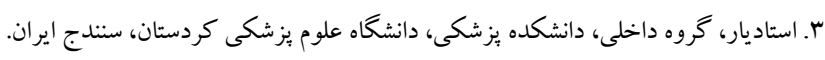

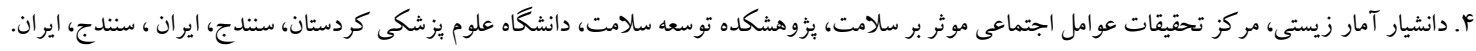

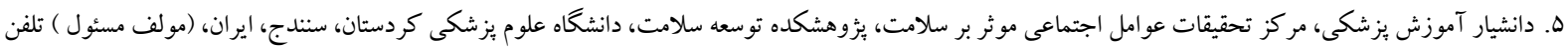

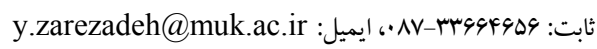

جكيده زمينه و هدف: دانش و اندوخته هاى يز شكان با مرور زمان دجار كاهش مى يابد، بنابراين جايكاه دوره هاى باز آموزى براى يزشكان بسيار

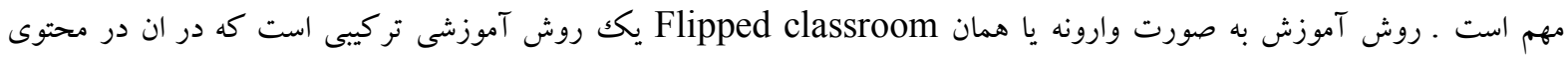
آموزشى با استفاده از فناوريهاى نوين خارج از كلاس به فراكيران ارائه مى شود ـ اين مطالعه با هدف تعيين بررسى تاثير استفاده از كلاس الهان

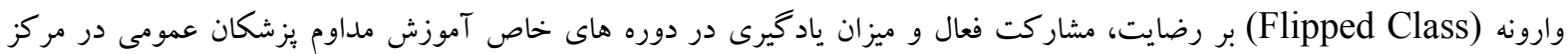

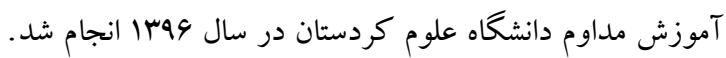

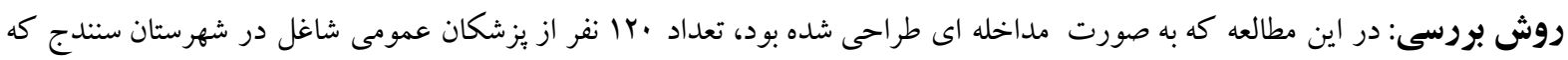

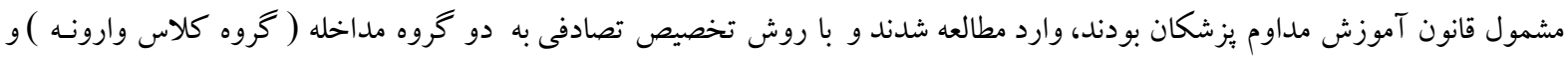

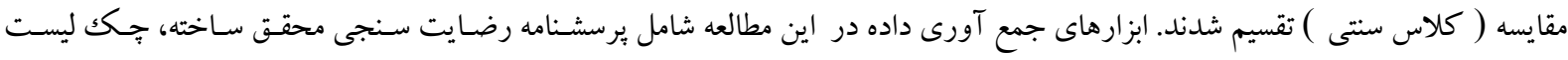

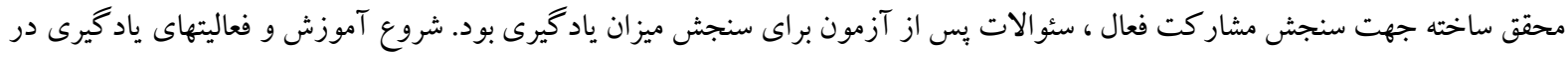

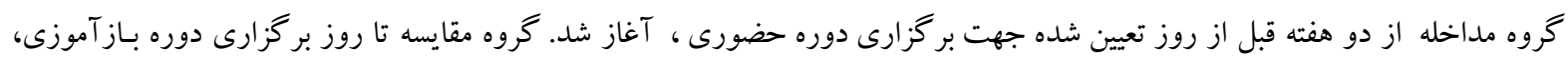

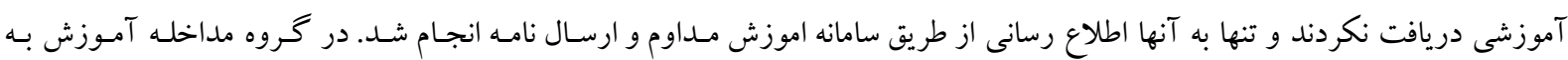

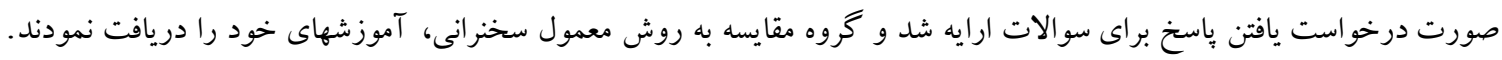

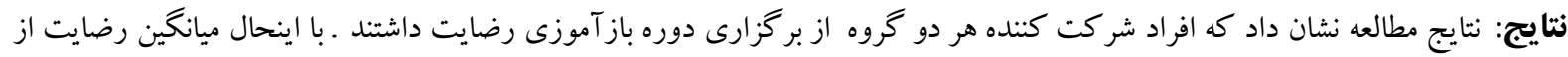

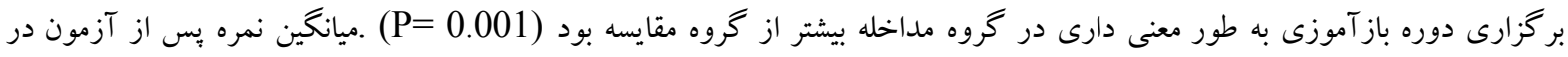

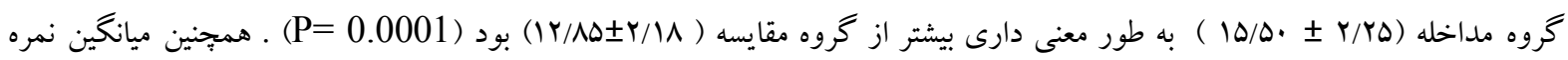

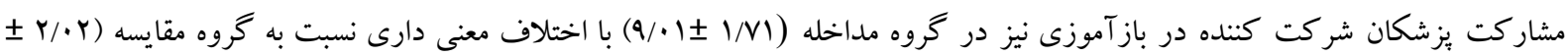

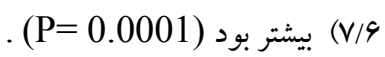
نتيجه كيرى: نتايج اين مطالعه نشان داد كه آموزش به روش وارونه (Flipped Classroom) دربرنامه هاى آموزش مداوم بز شيكان

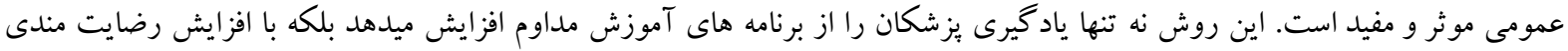

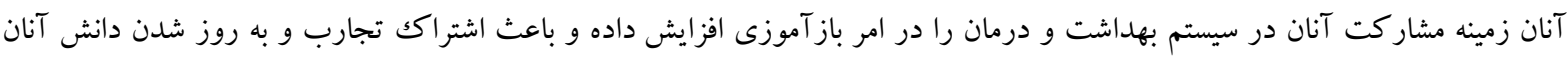


استفاده از روشهاى نوين آموزش مى تواند اثربخشى

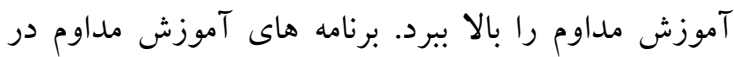
دانشخاههاى علوم يزشكى در اغلب موارد شباهت زيادى به آموزش دوره يزشكى دارد. مطالعات اندكى در كشور ما در مورد آموزش مداوم بزشكان انجام شده است كه بيشتر آنها نظر سنجى و رضايت سنجى و مطالعات توصيفى بوده است با اينحال مرورى بر اين مقالات نشان مى دهد كه بيشتر

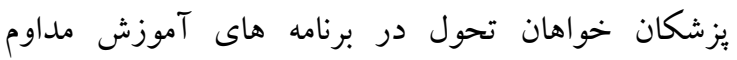

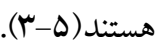
بر اساس نتايج مطالعه اى كه در سال 1rV9 ادر دانشگاه علوم

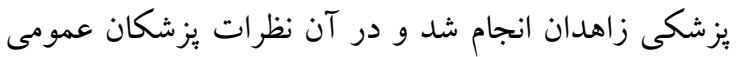

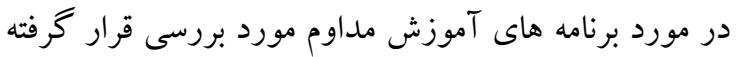
است، حدود •9 درصد افراد شر كت كننده در دوره هاى باز آموزى خواستار دگرگونى در روشهاى آموزشى و تاكيد

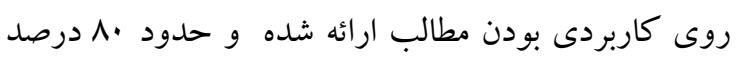

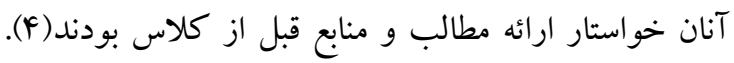

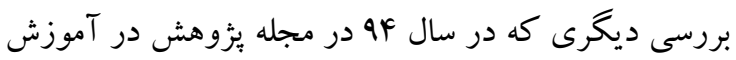

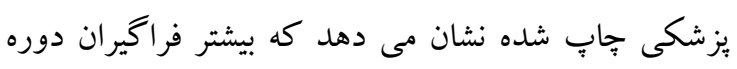

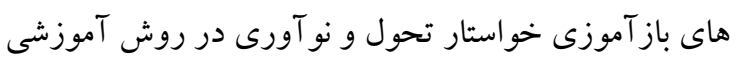
يس از دوران دانشگاه شده اند (ه). روش آموزش به صورت وارونه يكك روش تر كيبى است كه دان

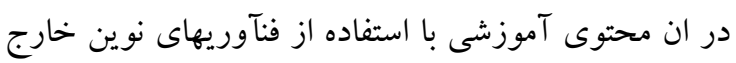
از كلاس و در قالب فايلهاى ويدئويى، فايلهاى مولتى مديا، فايلهاى صوتى و همجنين متون جايى تهيه مى شود و با

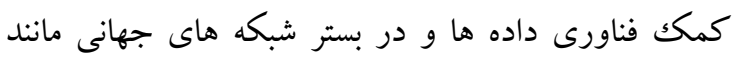

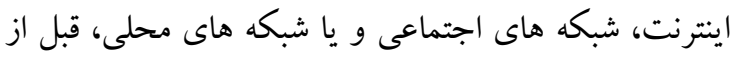

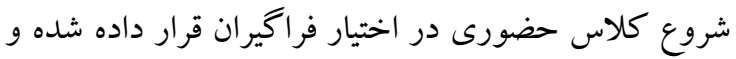
در كلاس با توجه به محتواى ارائه شده از قبل، بحث و تبادل نظر و رفع اشكال صورت مى گيرد. اين روش يادگيرى فعال و بر اساس تئورى آموزش بالغين طراحى شده است كه در

\section{مقدمه}

اندوخته هاى يادگيرى در هر سطحى از آموزش با مرور

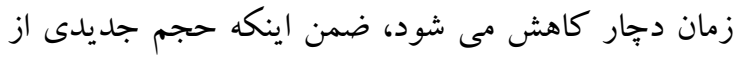

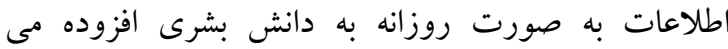

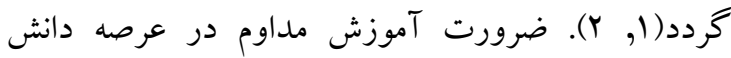
يزشكى و به ويزه جهت بزشكان از اهميت ويزه اى برخوردار است به طوريكه در سال هVIا قانون آموزش

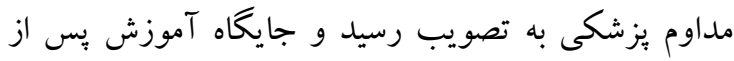

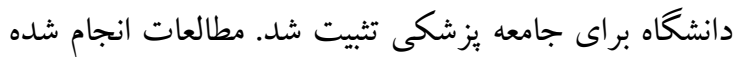
نشان ميدهند آموزشهاى با كيفيت، هزينه هاى بهداشتى لئى

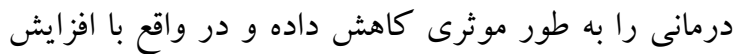
دانش ، مهارت و مديريت صحيح منابع، شكاف بين علم و

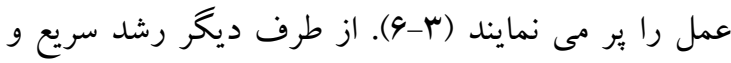
فراكير شدن اينترنت باعث بوجود آمدن تكنولوزيهاى آنلاين شده و تغييرات شكرفى در زمينه روشهاى نوين

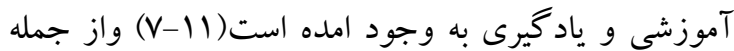

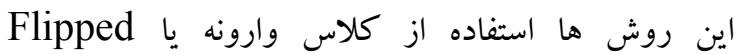
Classroom است كه در آن تغيير فضاى آموزشى از

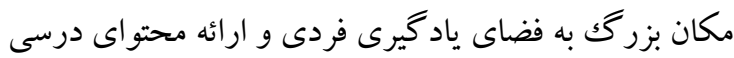
خارج از كلاس ، جلب مشاركت فراگيران، مرتبط ساختن

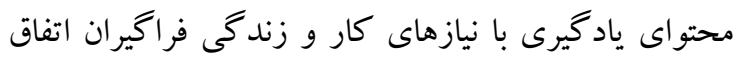

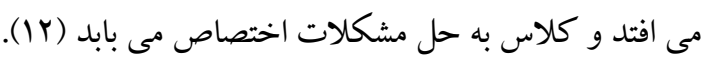

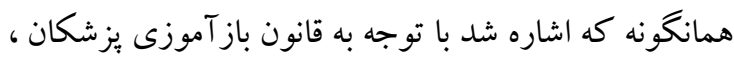

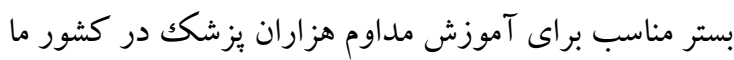
فراهم است ولى به نظر مى رسد كه از اين زمينه بسيار مناسب ميتوان به نحو بسيار موثر ترى استفاده كرد (ه). زمان

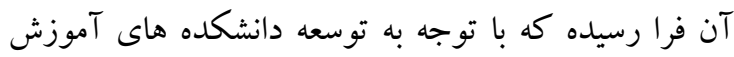

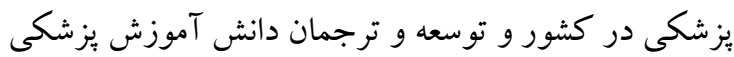
در سراسر كشور آموزش بعد از فارغ التحصيلى يزشكان نيز در سايه اين بيشرفت ملى و جهانى مورد بازنخرى قرار گيرد. 
بازآموزى، آموزشى دريافت نكردند و تنها به آنها اطلاع

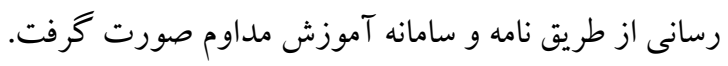

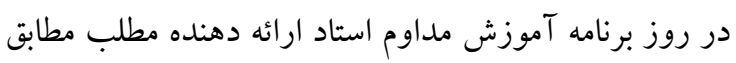

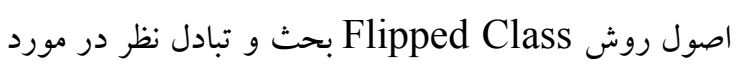

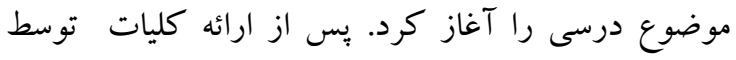

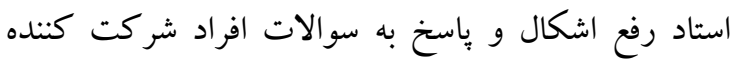

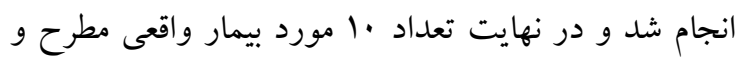
در مورد روش درمان و يا تغيير رزيم درمانى تصميم گيرى

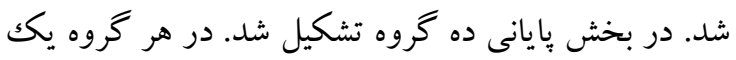

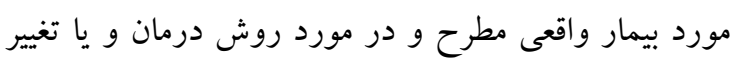

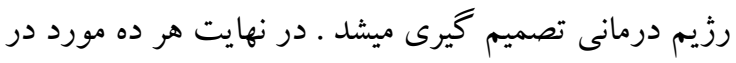

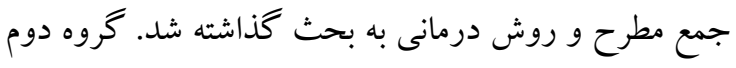

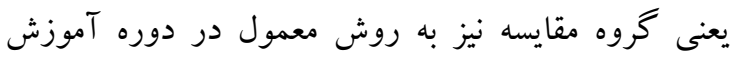

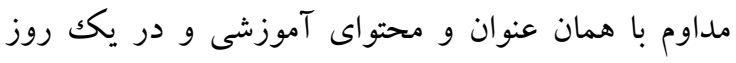

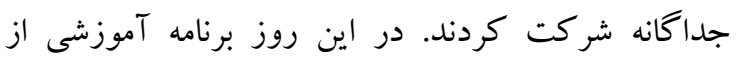

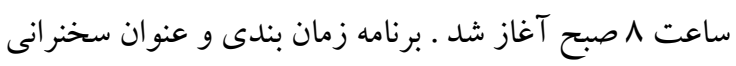

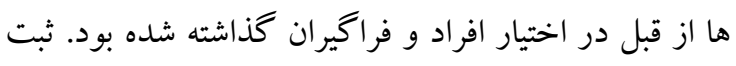

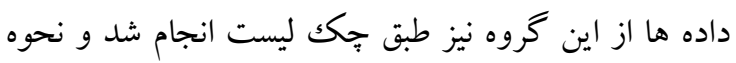
حضور فراكيران ثبت گرديد. سبس استاد مطابق برنامه زمان بندى شده مباحث خود را به صورت سخنرانى و با استفاده از

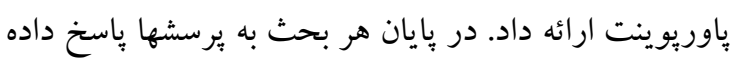

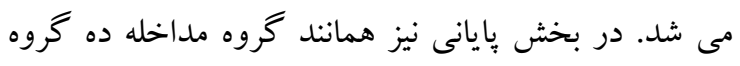

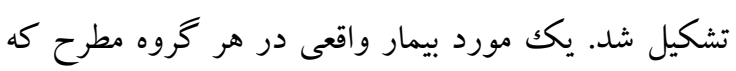

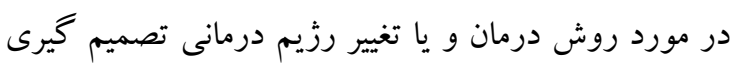

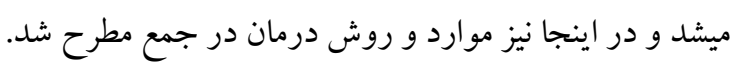

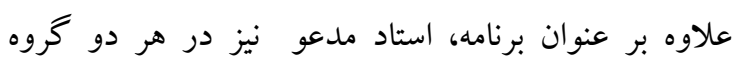

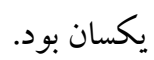

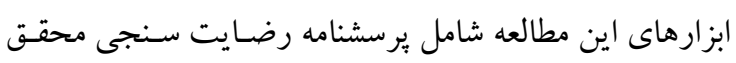

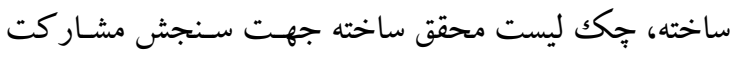

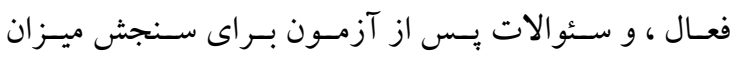

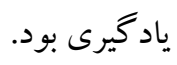

آن بر معنى دار بودن يادگيرى و ارتباط بلافصل آن با كار و

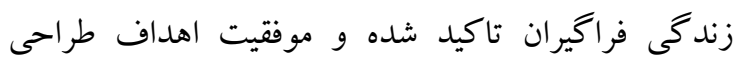
آموزشى براى بالغين را در جلب مشار كت فعال آنان ميداند. هر جند روش آموزش وارونه در ابتدى راه قرار دارد ولى

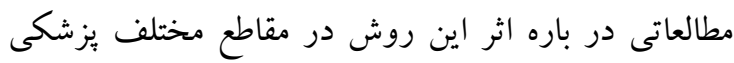

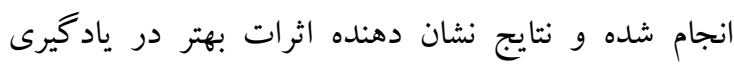

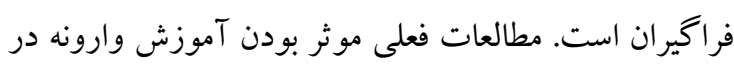

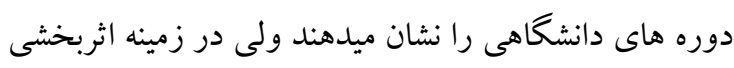

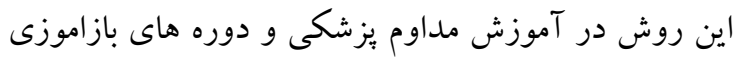

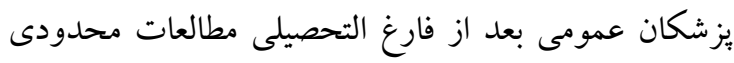
انجام شده است . اين مطالعه با هدف تعيين بررسى تاثير

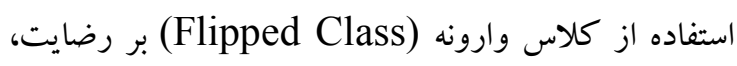

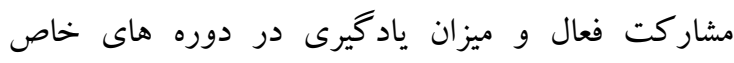

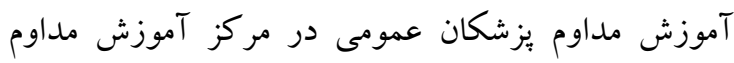
دانشگاه علوم كردستان در سال وهـا انجام شد.

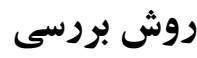

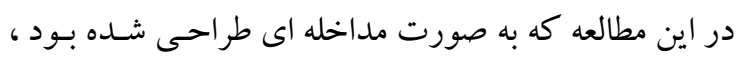
تعداد • rl انفر از يزشكان عمومى شاغل در شهرستان سنداج

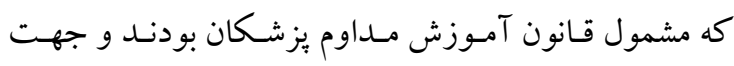
شر كت در برنامه آموزش مداوم تحت عنوان نقش انسـولين

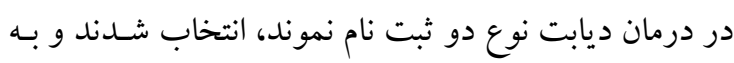
صورت تصادفى (جدول اعداد تصادفى) به دو گروه مداخله

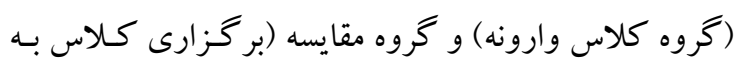

$$
\text { روش معمول) تقسيم شدند. }
$$

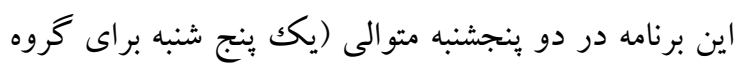
مداخله و ينجشنبه ديخر براى گروه مقايسه) در آبان ماه سال

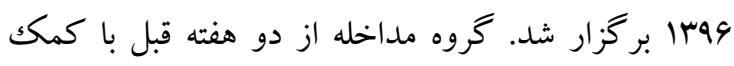
فضاى مجازى و همجنين ارسال جزوه، ويدئو و فايلهاى

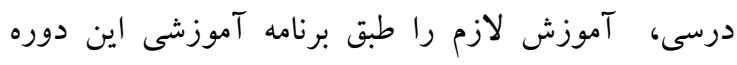

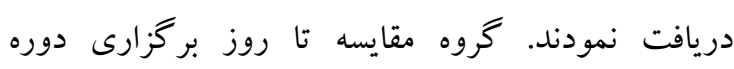


اين سوالات مطابق با اهداف آموزشى و محتواى آموزشى دوره در سطوح مختلف شناختى، نخرشى و مهارتى طراحى

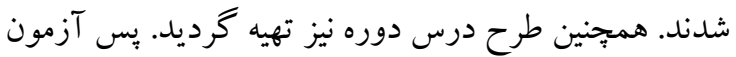
بر مبناى طرح درس تهيه شده و شامل ل 1 سوال بود. براى روايى اين آزمون ابتدا مدرس همكار طرح سوالات راطرح

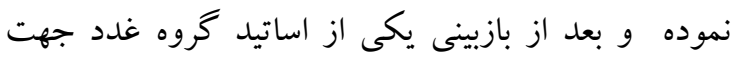
تطابق با طرح درس در اختيار يكى از اساتيد آموزش تُش يزشكى قرار داده شد و نظرات ايشان نيز اعمال گُرديد. در نهايت سوالات آزمون توسط مشاور آمارى طرح مورد تاييد قرار گرفت. و جهت سنجش پايايى پس آزمون اين

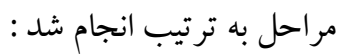

بودجه بندى سوالات بر اساس اهداف دوره و مباحث مطرح شده قرار گرفت لذل براى 9 هدف بـ آموزشى تعداد

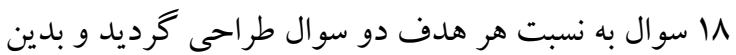
ترتيب روايى محتوا* و بوشش محتوا ***در آزمون تضمين گرديد. در خصوص هر سوال دقت گرديد كه سوال همان

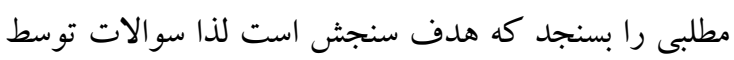
متخصص آموزش يزشكى و مدرس دوره مورد بررسى قرار

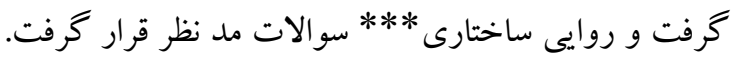
براى تضمين روايى بيشكويى **** كننده سوالات نهايت

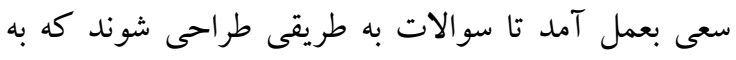

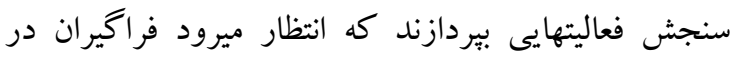

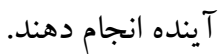

*content validity $* *$ content coverage $* * *$ construct validity $* * * *$ predictive validity

در نهايت آزمون يس از آمده شدن و طى مراحل بالا در اختيار ·r نفر از افراد جامعه آمارى قرار گرفت و در نهايت

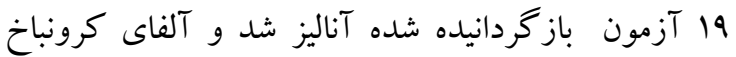
محاسبه گرديد كه عدد ایم · بدست آمد.

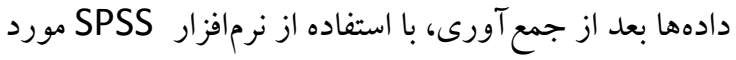
تجزيه و تحليل قرار گرفتند. براى مقايسه ميزان رضايتمندى، مشاركت فعال ، ميزان ياد گيرى و همجنين
برسشنامه رضايت سنجى در اين مطالعه شامل ^ سوال در

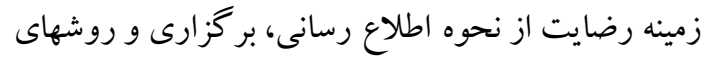
آموزشى استفاده شده در دوره، تاثير دوره در ارتقاء دانش

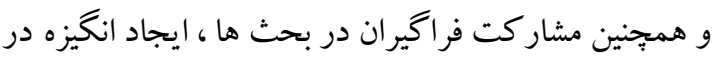
مطالعه و ياد گيرى، اشنايى با مطالب ارائه شده در كار گاه و تمايل به برگزارى دوره هاى بعدى با روش اموزشى ارائه شده بود كه هر كدام با مقياس بنجدرجهاى ليكرت (كاملاً

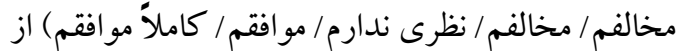
يكك تا ه نمره كذارى شده بودند. بر اساس مقياس

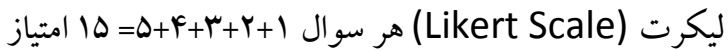
داشت كه بر ها كزينه تقسيم شده و عدد با به دست مى آيد كه اين عدد مبنا و نقطه برش رضايت فرد مى باشد و در تجزيه و تحليل رضايت سنجى مورد استفاده قرار گرفت. قبل از شروع مطالعه بايايى و روايى اين برسشنامه مورد بررسى قرار گرفت.در خصوص روايى برسشنامه رضايت

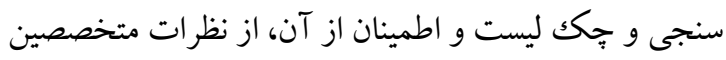
آمارى وآموزشى (دو نفر دكترى آموزش يزشكى، يك نفرمتخصص آمار، يك نفر متخصص داخلى و فعال در آموزش مداوم، يك نفر فوق تخصص گو ارش و فعال در

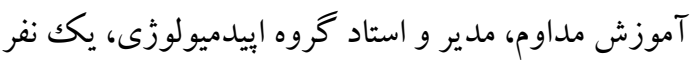

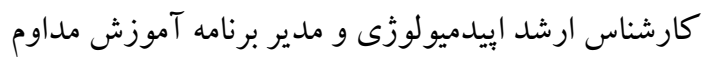

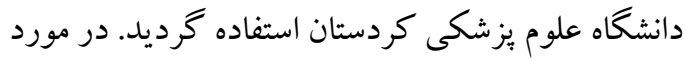

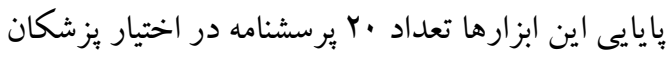

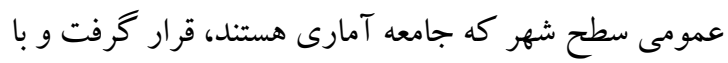
استفاده از نرم افزار آمارى SPSS آلفاى كرنباخ محاسبه كرديد كه عدد. ع • • به دست آمد.

براى سنجش مشاركت فعال از جکك ليست استفاده شد، با كمك اين جك ليست ميزان حضور فيزيكى، ساعات ورود

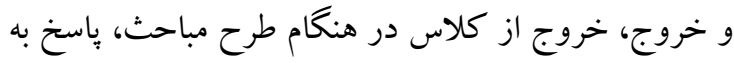

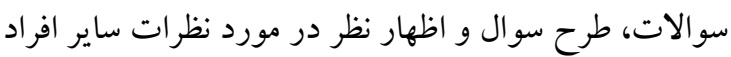

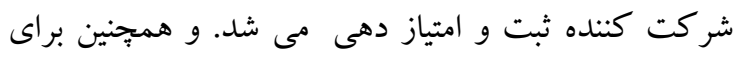
سنجش ميزان يادگيرى از سئوالات بِ بس آزمون استفاده شد. 


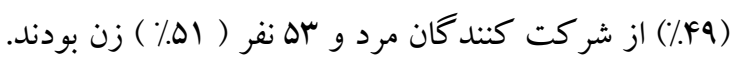
تفاوت معنى دارى بين گرووه مداخله و مقايسه از نظر

$$
\text { جنسيت وجود نداشت (P=./QF). }
$$

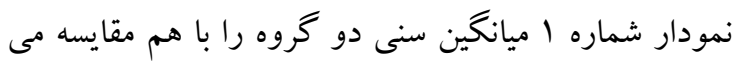

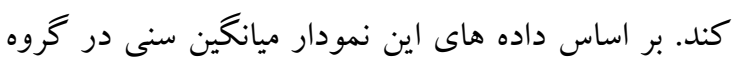

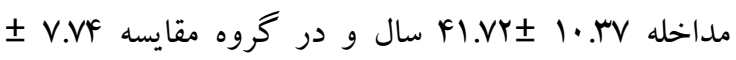

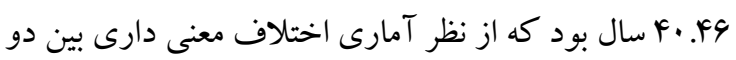

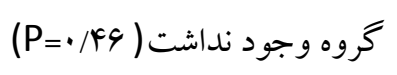

ميانگين سنى افراد بين دو گروه مورد مطالعه از ازمون Th

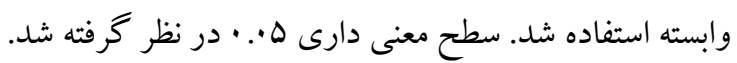

\section{نتايج}

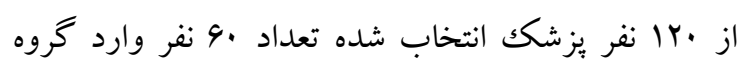

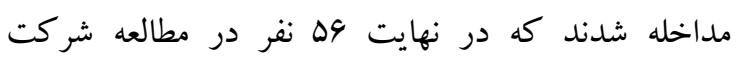

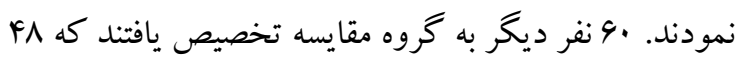

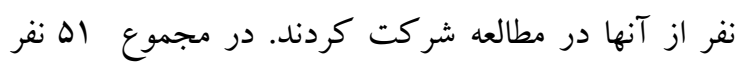

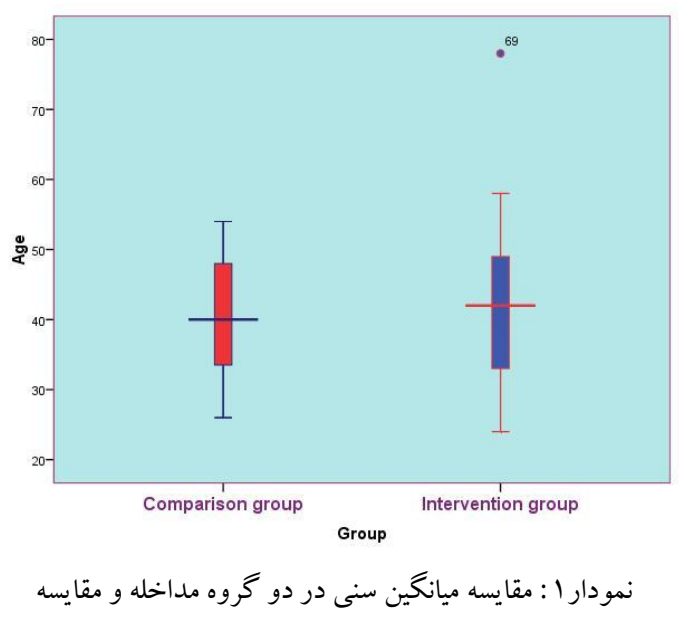

F/l/ اين اختلاف بين دو گروه از لحاظ امارى معنى دار بود

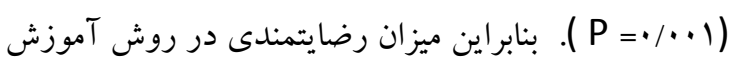
كلاس وارونه بيشتر از روش سنتى ارزيابى شد.
نتايج مطالعه نشان داد كه بر اساس مقياس ليكرت تمامى

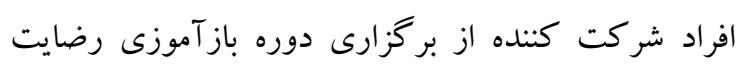

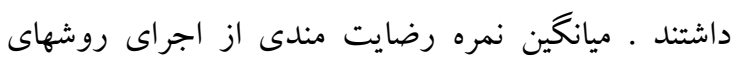

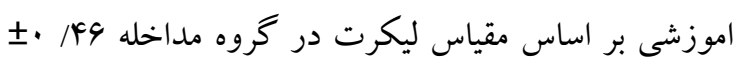




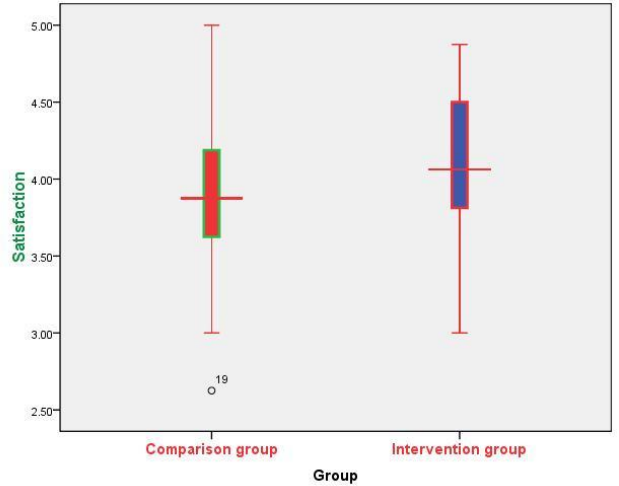

نمودار r : مقايسه ميانگين نمره رضايت از بركزارى دوره باز آموزى بر اساس مقياس ليكرت در دو گروه مطالعه

مداخله (1.VI (1. I. (9.) با اختلاف معنى دارى نسبت به

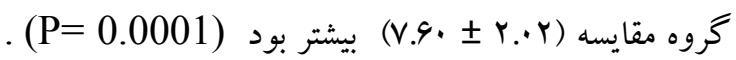
مقايسه ميانكين نمرات بس از آزمون و مشاركت بزشكان

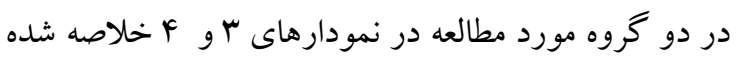
است
ساير نتايج مطالعه نشان داد كه ميانگين نمره كسب شده در بس آزمون جهت ارزيابى ميزان ياد كيرى شركت كند

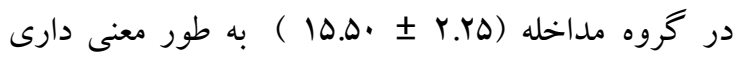

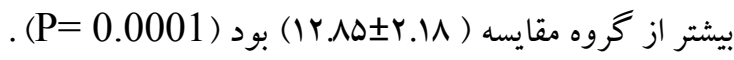
همجنين ميانگين نمره بدست امده در جّك ليست ارزيابى مشاركت يزشكان شركت كننده در بازآموزى در كروه

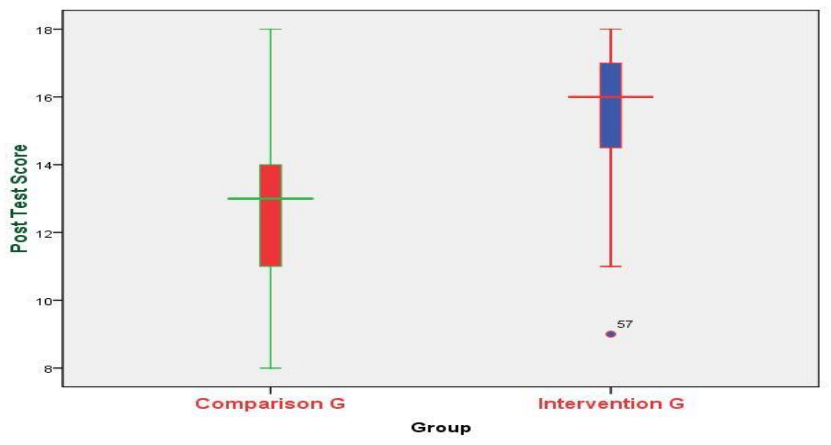

نمودار بـ: مقايسه ميانگين نمره پِ از آزمون در دو گروه مطالعه

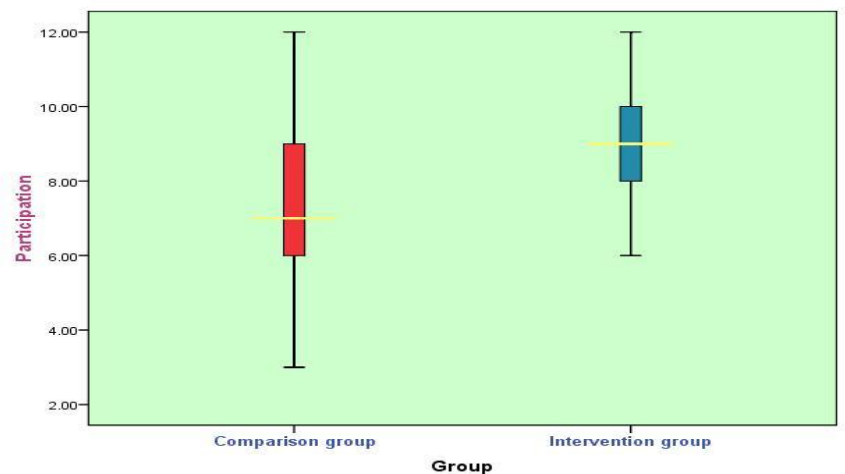

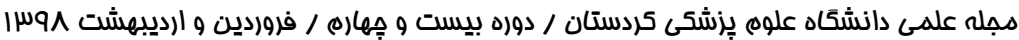


نمودار F: مقايسه ميانگين نمره مشار كت در دو گروه مطالعه

بر اساس يافته هاى اين مطالعه با وجود اينكه بر اساس مقياس

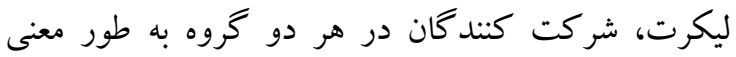

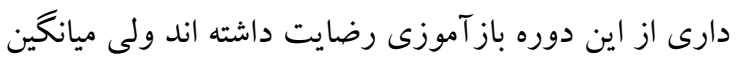

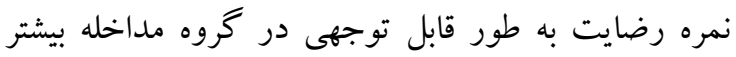
بوده است. بيشتر مطالعاتى كه در زمينه روش آموزشى وارونه انجام شده است در دانشكده هاى يزشكى و براى دوره هاى دانشجويى بوده است در حاليكه مقالات منتشر شده در مورد دوره هاى باز آموزى اندكك بوده و بيشتر در ميان يرستاران انجام شده است (Yr-19). يافته هاى تحقيق ، Klann و در سال Y.IV Gopalan نشان ميدهد دانشجويانى كه به روش آموزشى وارونه دوره سايكولوزى خود را كذرانده به طور معنى دارى بيشتر از دانشجويانى كه به روش معمول آموزش ديده بودند احساس راحتى و آمادكى بيشتر براى آزمونها را داشتند. در نهايت

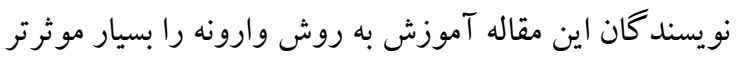
در دانشجويان بزشكى ارزيابى نمودند (1). در مر مطالعه

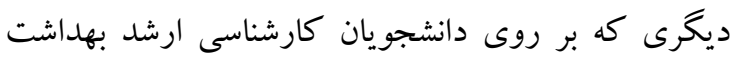
انجام شد و درس إيدميولوزى جهت تدريس به روش بر Flipped انتخاب شد ، نشان داده شد بيشتر اين دانشجويان اين روش آموزشى را بسيار موثرتر مى دانستند كه نه تنها

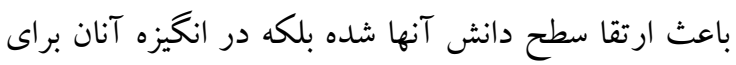
ادامه اين درس و ساير درسها در طول ترم موثر بوده است

ساير نتايج مطالعه حاضر نشان داد كه مشاركت يزشكان گروه مداخله نسبت به گروه مقايسه به طور معنى دارى بيشتر بوده و افرادى كه به روش وارونه آموزش ديده اند به مراتب در بحثهاى مربوط به باز آموزى مشاركت بيشترى داشته اند. ساير مطالعاتى هم كه در اين زمينه انجام شده تاكيد دارند كه روش Flipped يك روش دانشجو محور است نه

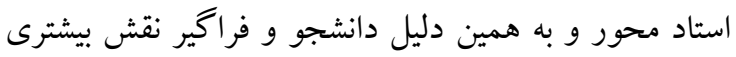

هدف اصلى از طراحى اين مطالعه بررسى تاثير روش

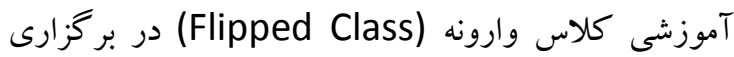
دوره هاى آموزش مداوم جهت يزشكان عمومى بود كه از اعضاى موثر در سيستم بهداشتى و درمانى بويا، به روز و موثر در ارائه خدمات يزشكى مدرن هستند. هدف كاربردى تحقيق اين بود كه در صورت موثر بودن اين روش با جايخزين كردن آن به جاى روش اموزشى به صورت سخنرانى و استاد محور كه هنوز هم يكى از شايعترين روشها در دانشكده هاى بزشكى نه تنها در ايران بلكه در بسيارى از كشورهاى جهان را تشكيل ميدهد (19) ، تغييرى اساسى در لرد آموزش بزشكى در دانشكده و بعدها در آموزش مداوم

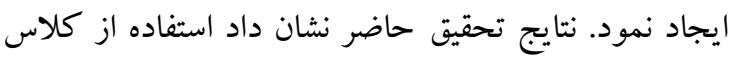
وارونه (Flipped Class) موجب افزايش رضايتمندى، مشاركت فعال و ميزان يادكيرى يزشكان عمومى در برغزارى دوره مذكور آموزش مداوم شده است. با توجه به يافته هاى مطالعه، ميانكين سنى افراد مشاركت

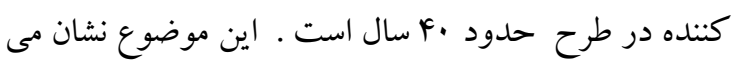

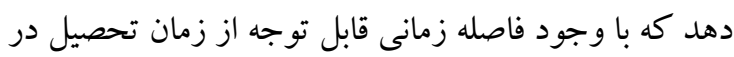

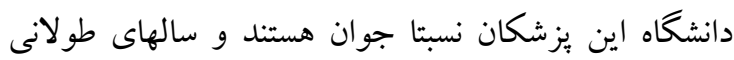
خدمت خواهند كرد. بنابراين افرادى تاثير كذار در عرصه بهداشت و درمان هستند كه اهميت آموزش مداوم و لزوم

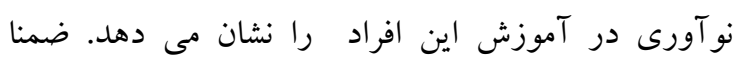

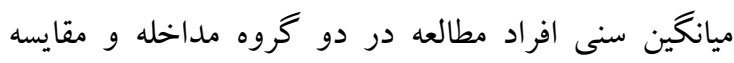

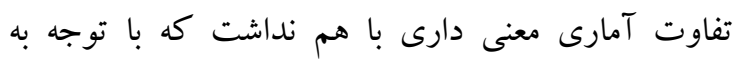
تخصيص تصادفى افراد به گروهها قابل قبول است. همجينين

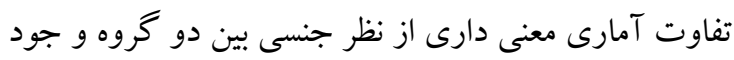

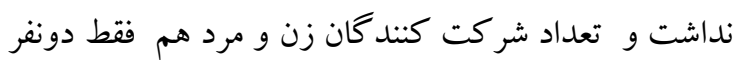
با هم اختلاف داشتند. 
وارونه در يادگيرى بهتر دانشجويان هستند(1, 19, IV بايد خاطر نشان كرد كه عليرغم مطالعات منفرد فراوان كه نشان دهنده تاثير مثيت كلاس وارونه بر يادگيرى فراكيران هستند و در اين مقاله به آنها اشاره شده است مرور نظام مند جن و همكاران (25) ضمن تاييد تاثير مثبت كلاس وارونه بر ميزان مشاركت و انغيزه فراخيران به فقدان شواهد قوى هـ مبنى بر تاثير اين روش بر ميزان افزايش دانش آنان اشاره كرده و لزوم مطالعات بيشتر را يادآور شده است.

\section{نتيجه كيرى}

نتايج اين مطالعه نشان داد كه آموزش به روش وارونه مى تواند يكك روش موثر در برنامه هاى (Flipped class) آموزش مداوم يزشكان عمومى باشد. اين روش نه تنها يادگيرى يزشكان را از برنامه هاى آموزش مداوم افزايش مى دهد بلكه با افزايش رضايت مندى آنان زمينه مشاركت آنان را در امر بازآموزى افزايش داده و باعث اشتراك تجارب و به روز شدن دانش آنان مى شود.با توجه به محدوديتهاى اين مطالعه به نظر ميرسد مطالعات بيشتر با بال طراحى هاى متفاوت و در موقعيت هاى مختلف يادگيرى ميتوانند تاثير اين روش را بر جنبه هاى مختلف يادگيرى

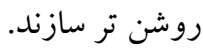

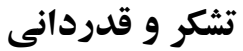

اين مطالعه مستخرج از بايان نامه دوره كارشناسى ارشد آموزش يزشكى روناكك مهاجر يور در دائه دانشكاه علوم

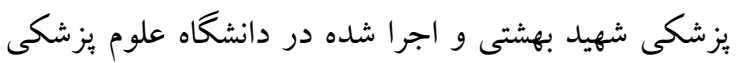
كردستان ميباشد. نويسند كان از اساتيد و مديران دانشكده آموزش يزشكى دانشگاه شهيد بهشتى و مديرو كار كنان آموزش مداوم دانشگاه علوم يزشكى كردستان و يز شكان

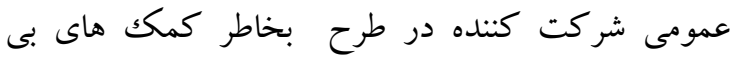
دريغشان تشكر ميكنند.
در فرايند آموزشى بازى مى كند(آ, ·r). بنابراين به نظر

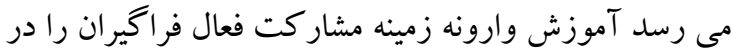
فرايند يادگيرى بيشتر مى كند و توان و ظرفيتهاى انها به كمكك دانش و مهارت استاد آمده تا ياد گيرى موثر تر باشد.

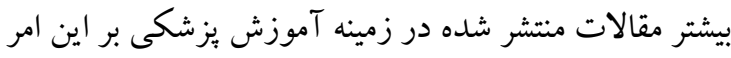
تاكيد مى كنند كه در آموزش وارونه اساس فعاليت آموزشى يادگيرى (Learning) ميباشد در حاليكه در روشهاى آموزشى معمول، ياددهى و تدريس (Teaching)

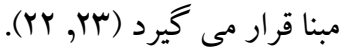
ديخر يافته هاى اين مطالعه نشان داد كه ميزان يادگيرى در كروه مداخله يعنى Flipped class به مراتب نسبت به كروه مقايسه بهتر بوده است. ميانگين نمرات آزمون خرفته

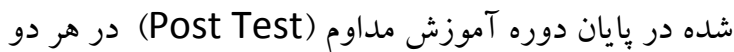
گروه نشان داد كه اين ميانگين به طور معنى دارى در گروه

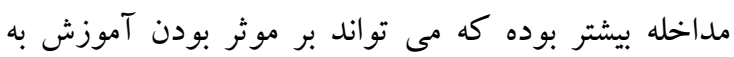

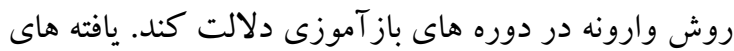
اين مطالعه مبنى بر ميزان يادگيرى بيشتر و مشار كت بيشتر در برد گروه كلاس وارونه ميتواند به اين علت باشد كه طبق تئورى

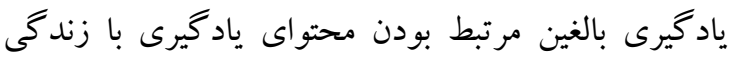

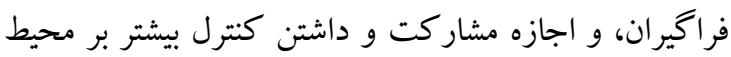

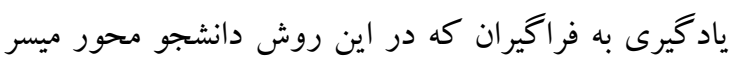
ميخردد براى فراكيران بالغ مهم است.

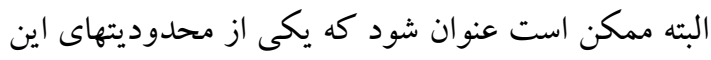

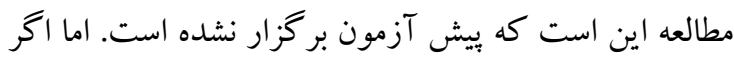

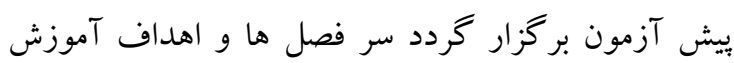
بصورت غير مستقيم از طريق سوالات در اختيار كروه

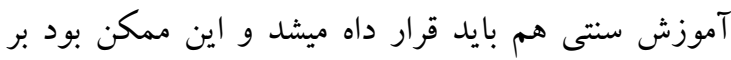
ترغيب گروه آموزش سنتى به مطالعه شخصى تاثير بكذارد

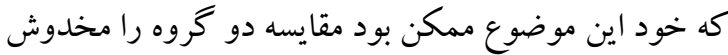
سازد. در ا با اينحال مطالعات متعددى در دسترس هستند كه همسو با اين مطالعه نشان دهنده موثر بودن آموزش به روش 



\section{Reference}

1. Gopalan C, Klann MC. The effect of flipped teaching combined with modified team-based learning on student performance in physiology. Adv Physiol Educ 2017;41:363-7.

2. Khanova J, Roth MT, Rodgers JE, McLaughlin JE. Student experiences across multiple flipped courses in a single curriculum. Med Educ 2015;49:1038-48

3. Haghani F, Shari atmadari A, Naderi E, Yousefi A. Teaching methods used by general practitioners' continuing education programs in Isfahan University of medical sciences. Iranian Journal of Medical Education 2003;3:15-21. [In Persian]

4. Borji A, Imani M, Moradi A. The study of General practitioners' views on the content of composed programs in Zahedan. Iranian Journal of Medical Education 2002;2:20-20. [In Pesian]

5. Arash A, Hesari Z, Alizadeh S, Broomand N. General practitioners assessment of continuing education programs in Golestan University of medical sciences. RME 2016;7:64-70. [In Pesian]

6 . Walsh $\mathrm{K}$. The cost of postgraduate medical education and continuing medical education: reexamining the status fifty years back. Korean J Fam Med 2015;36:46-9.

7. Wittich CM, Agrawal A, Wang AT, Halvorsen AJ, Mandrekar JN, Chaudhry S, et al. Flipped classrooms in graduate medical education: a national survey of residency program directors. academic medicine. Acad Med 2018;93:471-7.

8. Saunders A, Green R, Cross M. Making the most of person-centred education by integrating flipped and simulated teaching: An exploratory study. Nurse Educ Pract 2017;27:71-7

9. Kowalski K, Horner MD. Preparing Educators to Implement Flipped Classrooms as a Teaching Strategy. J Contin Educ Nurs 2015;46:346-7

10. Bullock A, Webb K. Technology in postgraduate medical education: a dynamic influence on learning?. Postgrad Med J 2015;91:646-50.

11. Wright EA, Brown B, Gettig J, Martello JL, McClendon KS, Smith KM, et al. Teaching and learning curriculum programs: recommendations for postgraduate pharmacy experiences in education. Am J Health Syst Pharm 2014;71:1292-302.

12. Pickering JD, Roberts DJH. Flipped classroom or an active lecture?. Clin Anat 2018;31:118-21.

13. Hew KF, Lo CK. Flipped classroom improves student learning in health professions education: a meta-analysis. BMC Med Edu 2018 12;18:38.

14. Pettit RK, McCoy L, Kinney M. What millennial medical students say about flipped learning. $\mathrm{dv}$ Med Educ Pract 2017;8:487-97.

15. Tainter CR, Wong NL, Cudemus-Deseda GA, Bittner EA. The "flipped classroom" model for teaching in the intensive care unit: rationale, practical considerations, and an example of successful implementation. J Intensive Care Med 2017;32:187-96.

16. Liebert CA, Lin DT, Mazer LM, Bereknyei S, Lau JN. Effectiveness of the surgery core clerkship flipped classroom: a prospective cohort trial. Am J Surg 2016;211:451-7

17. Carrick FR, Abdulrahman M, Hankir A, Zayaruzny M, Najem K, Lungchukiet P, et al. Randomized controlled study of a remote flipped classroom neuro-otology curriculum. Front Neurol 2017;8:349.

18. Moraros J, Islam A, Yu S, Banow R, Schindelka B. Flipping for success: evaluating the effectiveness of a novel teaching approach in a graduate level setting. BMC Me Edu 2015;15:27.

19. Nizamov IG, Sadykova TI. Quality of postgraduate medical education. Int J Risk Saf Med 2015;27:S93-4.

20. Hoover CA, Dinndorf-Hogenson GA, Peterson JL, Tollefson BR, Berndt JL, Laudenbach N. Flipped Classroom: Do Students Perceive Readiness for Advanced Discussion?. J Nurs Educ 2018;57(3):163-5

21. Gilboy MB, Heinerichs S, Pazzaglia G. Enhancing student engagement using the flipped classroom. J Nutr Educ Behav. 2015;47(1):109-14

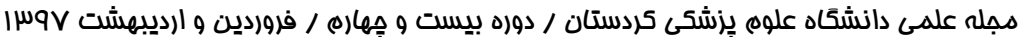


22. Dominguez LC, Vega NV, Espitia EL, Sanabria AE, Corso C, Serna AM, et al. Impact of the flipped classroom strategy in the learning environment in surgery: A comparison with the lectures. Biomedica 2015;35:513-21.

23. Tang F, Chen C, Zhu Y, Zuo C, Zhong Y, Wang N, et al. Comparison between flipped classroom and lecture-based classroom in ophthalmology clerkship. Med Edu Online 2017;22:1395679.

24. Chen F, Lui AM, Martinelli SM. A systematic review of the effectiveness of flipped classrooms in medical education. Medical Edu 2017;51:585-97.

25. Chen F, Lui AM, Martinelli SM. A systematic review of the effectiveness of flipped classrooms in medical education. Medical Edu 2017;51:585-97. 